\title{
Macromolecular Biosynthesis in Mycobacterium smegmatis ATCC 607 in the Presence of Antibodies to Mannophosphoinositides
}

\author{
By G. K. KHULLER, * ANJALI DOGRA, UMA MALIK AND \\ SATISH ASOTRA \\ Department of Biochemistry, Postgraduate Institute of Medical Education and Research, \\ Chandigarh-160 012, India
}

(Received 7 December 1983; revised 28 February 1984)

The biosynthesis of DNA, proteins, RNA and phospholipids in Mycobacterium smegmatis ATCC 607 was investigated by studying the incorporation of radiolabelled components in the presence of antiserum to mannophosphoinositides. The antiserum had an inhibitory effect on the rate of synthesis of these macromolecules. However, the inhibition was greater when antibody was present together with complement.

\section{INTRODUCTION}

The bactericidal action of serum on Gram-negative bacteria has been extensively studied (Melching \& Vas, 1971) and it was shown to be complement dependent (Blanden et al., 1966; Muschel, 1965), while limited information is available regarding the action of serum on Grampositive micro-organisms.

Recently, we reported that antiserum to mannophosphoinositides in the absence of complement partially inhibited the growth, as well as phospholipid biosynthesis of Mycobacterium smegmatis ATCC 607 (Penumarti \& Khuller, 1982). Mannophosphoinositides, components of the mycobacterial outer surface (Akamatsu et al., 1966), are probably accessible to specific antibodies in the surrounding medium. With a view to better understanding the events which occur before phagocytosis and the ultimate fate of the bacterial cell in vivo, the effect of mannophosphoinositide antibodies on the biosynthesis of various macromolecules in $M$. smegmatis ATCC 607 was studied in the presence and absence of complement.

\section{METHODS}

Culture and growth of the organism. A culture of M. smegmatis ATCC 607 was maintained on Lowenstein-Jensen

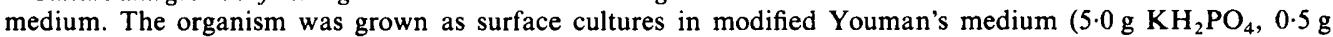
$\mathrm{MgSO}_{4} .7 \mathrm{H}_{2} \mathrm{O}, 2.5 \mathrm{~g}$ sodium citrate, $40 \mathrm{~g}$ glycerol, $5 \mathrm{~g}$ asparagine and $0.05 \mathrm{~g}$ ferric ammonium citrate dissolved in 11 distilled water) at $37^{\circ} \mathrm{C}$. The medium was inoculated with $24 \mathrm{~h}$ cultures and organisms were harvested at the exponential phase of growth after $4 \mathrm{~d}$.

Preparation of antigen and immunization. Phospholipids were isolated as described by Taneja \& Khuller (1981) and Penumarti \& Khuller (1982). Mannophosphoinositides (mannosides) were isolated from other phospholipids by thin-layer chromatography on silica gel $\mathrm{G}$ plates with chloroform/methanol/7 M-ammonia $(65: 25: 4$, by vol.) as the developing solvent. For the isolation of large quantities of mannosides, the dry column chromatography technique of Vishwanathan \& Leley (1976) was used.

Mannoside-bovine serum albumin complexes were prepared by the procedure of Inoue \& Nojima (1967). Rabbits weighing $1.5-2.0 \mathrm{~kg}$ were immunized with mannoside-methylated bovine serum albumin complexes suspended in Freund's incomplete adjuvant (Khuller \& Subrahmanyam 1971). Each rabbit was injected with $62.5 \mathrm{mg}$ phospholipid antigen. The rabbits were bled by cardiac puncture and separated serum was checked for the presence of antibodies by kaolin agglutination and Ouchterlony's double-diffusion techniques (Khuller \& Subrahmanyam, 1981). Complement was inactivated by incubation of the serum at $56^{\circ} \mathrm{C}$ for $30 \mathrm{~min}$.

Macromolecular biosynthesis. All the radioisotopes were supplied by Bhabha Atomic Research Centre, Bombay, India. $\left[{ }^{14} \mathrm{C}\right] \mathrm{Leucine}$ (specific activity $13.46 \mathrm{mCi} \mathrm{mmol}^{-1}, 498 \mathrm{MBq} \mathrm{mmol}{ }^{-1}$ ) was used to follow protein bio- 
synthesis at $1 \mu \mathrm{Ci}$ per $2 \mathrm{~g}$ cells, $\left[{ }^{14} \mathrm{C}\right]$ uracil (specific activity $54 \mathrm{mCi} \mathrm{mmol}^{-1}, 1.99 \mathrm{GBq} \mathrm{mmol}^{-1}$ ) for RNA biosynthesis as $2 \mu \mathrm{Ci}$ per $2 \mathrm{~g}$ cells, $\left[{ }^{3} \mathrm{H}\right]$ thymidine (specific activity $6.7 \mathrm{mCi} \mathrm{mmol}^{-1}, 248 \mathrm{MBq} \mathrm{mmol}^{-1}$ for DNA biosynthesis at $3 \mu \mathrm{Ci}$ per $2 \mathrm{~g}$ cells, and carrier-free ${ }^{32} \mathrm{P}$ in the form of orthophosphate in dilute $\mathrm{HCl}$ for phospholipid biosynthesis.

Cells were harvested by filtration after $4 \mathrm{~d}$ growth and resuspended in the same fresh medium. Decomplemented and complemented normal rabbit serum as well as decomplemented and complemented mannoside antiserum were added to respective cultures at a concentration of $15 \%(\mathrm{v} / \mathrm{v})$ (Penumarti \& Khuller, 1982). Radioactively labelled compounds $\left(\left[{ }^{3} \mathrm{H}\right]\right.$ thymidine, $\left[{ }^{14} \mathrm{C}\right]$ uracil and $\left[{ }^{14} \mathrm{C}\right]$ leucine $)$ were added to $0 \cdot 7-0 \cdot 8 \mathrm{~g}$ of cells (wet wt) suspended in tubes containing $10 \mathrm{ml}$ sterile Youman's medium. Cells were incubated at $37^{\circ} \mathrm{C}$ with constant shaking. At various times, a $1 \mathrm{ml}$ sample of the cell suspension was removed and added to an equal volume of $10 \%(\mathrm{w} / \mathrm{v})$ trichloroacetic acid solution. The cells were harvested by centrifugation at $1200 \mathrm{~g}$ and washed with distilled water to remove the adhering isotope. The pellet was digested in $30 \%(\mathrm{w} / \mathrm{v}) \mathrm{KOH}$ and a sample was taken for the assay of radioactivity.

Phospholipid biosynthesis. Exponential phase ( $4 \mathrm{~d}$ old) cells of $M$. smegmatis were harvested by filtration and suspended in fresh Youman's medium (the phosphate of the medium was replaced by $0.242 \%, w / v$, Tris) at a concentration of $70 \mathrm{mg}$ wet wt bacteria $\mathrm{ml}^{-1}$. Cells were incubated for $2 \mathrm{~h}$ at $37^{\circ} \mathrm{C}$ with constant shaking. Complemented and decomplemented normal and immune sera were added to the respective flasks followed by the addition of the carrier-free ${ }^{32} \mathrm{PO}_{4}^{3-}(20 \mu \mathrm{Ci}$ per $\mathrm{ml}$ cell suspension). Incubation was continued for various time intervals. Cells were suspended in chloroform/methanol $(2: 1, \mathrm{v} / \mathrm{v})$ and stirred for $5 \mathrm{~h}$ on a magnetic stirrer. The suspension was filtered and the filtrate was washed as described by Folch et al. (1957). The purified lipids were used for further analysis of phospholipids by thin-layer chromatography; spots corresponding to each component were scraped from the chromatographic plates and their radioactivity was measured (Taneja \& Khuller, 1981).

Statistical analysis. Differences between various types of cultures were calculated by Student's $t$ test. The $P$ values were calculated for $(a)$ complemented antiserum (CAs) versus complemented normal serum (CNs), (b) decomplemented antiserum (DAs) versus decomplemented normal serum (DNs), and (c) the effect of complement was determined by comparing decomplemented antiserum (DNs-DAs) versus effect of complemented antiserum (CNs-CAs).

\section{RESULTS AND DISCUSSION}

There was a continuous increase in the uptake of all the different radioactive precursors with time (from 15 to $60 \mathrm{~min}$ ) in both types of cultures, viz. antiserum- as well as normal serumtreated cells, which served as a control. The use of normal serum as control in this study rules out the possibility of interference by other serum components (for a review see Taylor, 1983). These results were independent of the presence or absence of the complement.

\section{Effect on lipid biosynthesis}

There was a continuous decline in the uptake of radiolabelled precursor for the total (Fig. 1) as well as individual phospholipids (Table 1) in the presence of decomplemented as well as complemented antiserum when compared to normal serum $(P<0.001-<0.05)$. However, the inhibition was greater in the presence of complemented antiserum. This inhibitory effect at

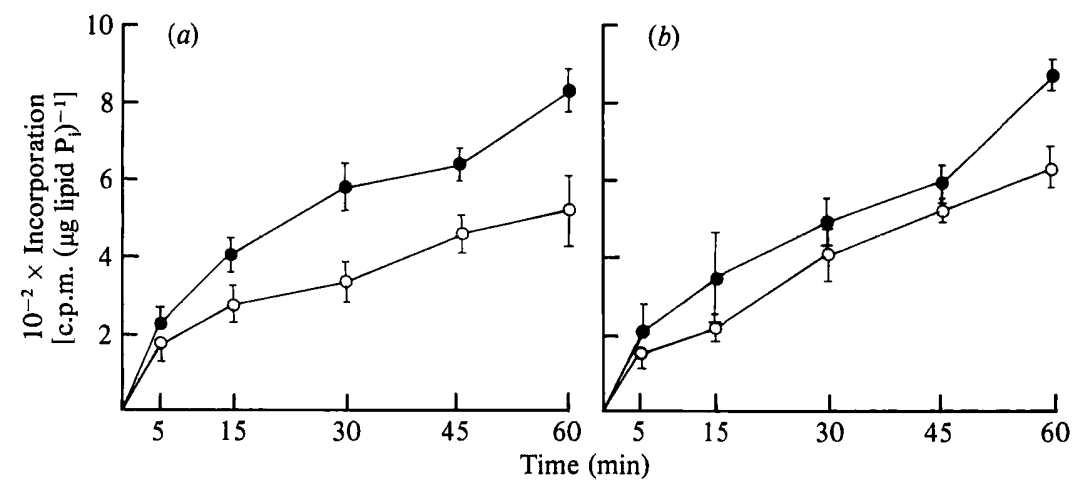

Fig. 1. Effect of mannoside antiserum on the incorporation of ${ }^{32} \mathrm{PO}_{4}^{3-}$ into total lipids $(a)$ in the presence and $(b)$ in the absence of complement. $\bigcirc$, Mannoside antiserum; $\bigcirc$, normal rabbit serum. Values are means \pm SE of four different observations. 
Table 1. Effect of mannoside antiserum on the incorporation of ${ }^{32} \mathrm{PO}_{4}^{3-}$ into individual phospholipid components in the presence and absence of complement

\begin{tabular}{|c|c|c|c|c|}
\hline \multirow[b]{3}{*}{ Macromolecule } & \multicolumn{4}{|c|}{$\begin{array}{c}\text { Incorporation } \\
\left.\text { [c.p.m. }(\mu \mathrm{g} \text { lipid phosphorus })^{-1} \text { at } 60 \mathrm{~min}\right]^{*}\end{array}$} \\
\hline & \multicolumn{2}{|c|}{ Complemented } & \multicolumn{2}{|c|}{ Decomplemented } \\
\hline & $\begin{array}{l}\text { Anti- } \\
\text { serum }\end{array}$ & $\begin{array}{l}\text { Normal } \\
\text { serum }\end{array}$ & $\begin{array}{l}\text { Anti- } \\
\text { serum }\end{array}$ & $\begin{array}{l}\text { Normal } \\
\text { serum }\end{array}$ \\
\hline dyl-inositomannosides & $569 \pm 40$ & $784 \pm 33$ & $613 \pm 52$ & $900 \pm 20$ \\
\hline ini & $355 \pm 10$ & $608 \pm 50$ & $428 \pm 15$ & $552 \pm 30$ \\
\hline atidyl-ethanolmine & $256 \pm 20$ & $485 \pm 35$ & $308 \pm 15$ & $488 \pm 10$ \\
\hline
\end{tabular}

* Values are means \pm SE of four independent observations. See text for statistical significance of these observations.

Table 2. Effect of mannoside antiserum on the incorporation of labelled precursors into DNA, $R N A$ and protein in the presence and absence of complement

$\begin{array}{lccccc}\text { Macromolecule } & \overbrace{\begin{array}{c}\text { Anti- } \\ \text { serum }\end{array}}^{\text {Complemented }} \begin{array}{c}\text { Normal } \\ \text { serum }\end{array} & \overbrace{\begin{array}{c}\text { Anti- } \\ \text { serum }\end{array}}^{\text {Decomplemented }} & \begin{array}{c}\text { Normal } \\ \text { serum }\end{array} \\ \text { DNA } & 3700 \pm 570 & 6400 \pm 340 & 5300 \pm 290 & 6500 \pm 420 \\ \text { RNA } & 3170 \pm 180 & 7300 \pm 530 & & 5920 \pm 160 & 7200 \pm 850 \\ \text { Protein } & 325 \pm 27 & 452 \pm 68 & 350 \pm 29 & 430 \pm 30 \\ & * \text { Values are means } \pm \text { SE of four independent observations. } & \end{array}$

60 min was significant for all the phospholipid components $(P<0.001-<0.05)$ except for phosphatidylinositomannosides, where the effect was insignificant. However, at other time intervals significant inhibition was noted $(P<0.01$ at $30 \mathrm{~min}$ and $P<0.001$ at $45 \mathrm{~min})$. The observed decrease in the uptake of labelled phosphate could be due to the alteration produced in the membrane permeability by mannoside antibodies in the presence of complement. These results are in good agreement with those of a study with Gram-negative bacteria in which complement dependent serum bactericidal actions have been reported (Melching \& Vas, 1971).

\section{Effect on macromolecular biosynthesis}

After examining the effect of antibodies and complement on the biosynthesis of phospholipids, the biosynthesis of other macromolecules such as DNA, RNA and protein under similar conditions was examined. The results obtained after $60 \mathrm{~min}$ exposure are presented in Table 2. The uptake of $\left[{ }^{3} \mathrm{H}\right]$ thymidine into DNA decreased continuously in the presence of decomplemented as well as complemented antiserum $(P<0.001-<0.05)$ when compared to normal serum. The extent of inhibition in the presence of complemented antiserum was greater than that found with decomplemented antisera $(P<0.05)$. The uptake of $\left[{ }^{14} \mathrm{C}\right]$ uracil into RNA at different time intervals also decreased in the presence of decomplemented or complemented antiserum. After $60 \mathrm{~min}$ there was a slight inhibition with complemented antisera $(P<0 \cdot 1)$ and a significant inhibition in the presence of decomplemented antiserum $(P<0.001)$. The complemented versus decomplemented sera also exhibited a significant difference $(P<0.001)$ for RNA synthesis. Protein synthesis was also affected under the same conditions, although the results were marginally significant $(P<0 \cdot 1)$. The observed decrease in the incorporation of radiolabelled components into various macromolecules, viz. DNA, RNA and protein, when exposed to mannoside antibodies is probably a consequence of the altered mycobacterial cell metabolism in the presence of antiserum, as has been suggested for Gram-negative bacteria (David \& Wedgewood, 1965). 
Antibodies to membrane glycolipids of Mycoplasma pneumoniae were reported to inhibit the metabolism of the organism (Razin et al., 1978), which was compatible with our observations with mycobacteria. Antibodies, being large molecules, cannot penetrate the cell barrier and probably their effect is mediated by an interaction with cell surface receptors. The fact that the inhibition observed in the protein synthesis is reflected in the DNA and RNA biosynthesis suggests that the processes of both replication and transcription are affected by the immune serum. However, the extent of inhibition with mannoside antibodies was greater in the presence of complement. Complement exerts a variety of effects on the properties and functions of biological membranes by binding to membrane receptors (Lachman, 1968).

The decreased incorporation of respective precursors into different macromolecules in mycobacteria occurs as a consequence of the interaction of antigen-antibody complex with the complement. The growth inhibition of $M$. smegmatis in the presence of immune serum to mannosides as reported earlier (Penumarti \& Khuller, 1982) may be the consequence of bactericidal action or decreased biosynthesis of all the macromolecules. An investigation of the mechanisms by which antimannoside antibodies cause these alterations in macromolecule biosynthesis in mycobacteria is in progress.

This study was financed, in part, by a grant from the Indian Council of Medical Research. We wish to acknowledge the contributions of Miss Anita Mehta in the initial part of this work.

\section{REFERENCES}

Akamatsu, Y., ONo, Y. \& NoJima, S. (1966). Phospholipid patterns in subcellular fraction of Mycobacterium phlei. Journal of Biochemistry 61, 96-102.

Blanden, H. A., Evans, R. T. \& Mergenhagen, S. E. (1966). Lesions in Escherichia coli membranes after action of antibody and complement. Journal of Bacteriology 91, 2377-2381.

DAVID, S. D. \& WeDGewood, R. J. (1965). Kinetics of the bactericidal action of normal serum on Gramnegative bacteria. Journal of Immunology 95, 75-79.

Folch, J., Lees, M. \& Stanley, G. H. S. (1957). A simple method for the isolation and purification of total lipids from animal tissues. Journal of Biological Chemistry 226, 497-509.

INoUe, K. \& NoJima, S. (1967). Immunochemical studies of phospholipids. III. Production of antibody to cardiolipin. Biochimica et biophysica acta 144, 409414.

Khuller, G. K. \& Subrahmanyam, D. (1971). Antigenicity of phosphatidylinositomannosides of Mycobacterium tuberculosis. Immunochemistry $\mathbf{8}$, 251-256.

LaChman, P. J. (1968). Complement. In Clinical Aspects of Immunology, 2nd edn, p. 339. Edited by P. G. H. Cell \& R. R. A. Coombs. Oxford: Blackwell Scientific Publications.

Melching, L. \& VAS, S. I. (1971). Effect of serum components on Gram-negative bacteria during bactericidal reactions. Infection and Immunity 3, 107115 .

MUSCHEL, L. H. (1965). Immune bactericidal and bacteriolytic reaction. CIBA Foundation Symposia pp. 155-168.

Penumarti, N. \& KhUller, G. K. (1982). Influence of antibodies to mannophosphoinositides on phospholipid synthesis in Mycobacterium smegmatis ATCC 607. Infection and Immunity 37, 884-891.

Razin, S., Prescott, B. \& Chonoex, R. M. (1970). Immunogenicity of Mycoplasma pneumoniae glycolipids: a novel approach to the production of antisera to membrane lipids. Proceedings of the National Academy of Sciences of the United States of America 67, 590-597.

Taneja, R. \& Khuller, G. K. (1981). Phospholipid metabolism in Mycobacterium smegmatis ATCC 607 grown at $37^{\circ} \mathrm{C}$ and $27^{\circ} \mathrm{C}$. Archives of Microbiology 129, 81-84.

TAYLOR, W. (1983). Bactericidal and bacteriolytic activity of serum against Gram-negative bacteria. Microbiological Reviews 47, 46-83.

Vishwanathan, C. V. \& Leley, V. K. (1976). Simple technique for the development of dry column chromatography. Journal of Chromatography 128, 302-303. 